Manuscript Number: JMPO-D-15-00511R1

Title: Exploring the applicability of biological and socioeconomic tools in developing EAFM plans for data absent areas: Spinner dolphin EAFM for Kalpitiya, Sri Lanka

Article Type: Full Length Article

Keywords: Ecosystem approach to fisheries management; Spinner dolphin; Stella longirostris; Stakeholder engagement; Gulf of Mannar

Corresponding Author: Miss. Lauren Mattingley, MSc.

Corresponding Author's Institution:

First Author: Lauren Mattingley, MSc.

Order of Authors: Lauren Mattingley, MSc.; Sevvandi Jayakody; Beth E scott

Abstract: The ecosystem approach to fisheries management (EAFM) methodology is currently considered the preferred option for long-term sustainability of fisheries and ecosystem services and is widely popularised. Manuals, guidelines and training have been given to many nations, but the actual existence and execution of an EAFM plan is rare. The applicability and relevance of biological and socioeconomic tools to follow EAFM planning guidelines in a data absent area were explored in Kalpitiya, northwest Sri Lanka, where there is a population of spinner dolphins that the local community are especially dependent on through tuna-dolphin association fishing and dolphin-watching tourism. This paper provides background to the design and collection of information leading to the formulation of an EAFM management plan. Scoping and the determination of a fishery management area were completed through stakeholder consultations using a combination of interviewer-administered questionnaires, interviews, meetings, dolphin distribution data and existing management plans. Threats and stakeholder prioritisation were compiled and the final agreed fisheries management area covers a total area of $2445 \mathrm{~km} 2$ adjacent to the Kalpitiya peninsula. The completed EAFM plan contains 4 goals, 16 actions and 72 sub-actions agreed by stakeholders. It was concluded that both willingness of higher level stakeholders responsible for implementing regulations and working with grass-root level stakeholders are critical in developing a realistic and implementable EAFM plan. This work also highlights how data absence should not remain the bottleneck that hinders moving forward with EAFM approaches. 
School of Biological Sciences,

University of Aberdeen,

Tillydrone Avenue,

Aberdeen

AB24 2TZ

$7^{\text {th }}$ December 2015

Dear editor,

I present to you the manuscript entitled - Exploring the applicability of biological and socioeconomic tools in developing EAFM plans for data absent areas: Spinner dolphin EAFM for Kalpitiya, Sri Lanka. We are exclusively submitting this work to the journal Marine Policy for publication consideration as an original research article.

This study is the first of its kind to document the methods of creation and development of an EAFM plan in a data poor region that has strong local support for immediate implementation. We explored and applied straightforward types of data collection (questionnaires, and very limited at-sea surveys) and analyses to obtain the baseline information required to construct an informed EAFM management proposal. This work highlights that EAFM implementation can occur quite rapidly (with this project taking under 4 months) with a modest amount of interaction with willing higher level and grass roots stakeholders. It also demonstrates the merit of using questionnaires and standard GIS tools as part of the scoping process in future EAFM planning. The main outcome of the study was a full, stakeholder approved EAFM plan that stands ready for implementation. This work is a marriage of social, ecological and political principles so we believe it will be of interest to readers with a strong interest in designing pragmatic marine management solutions.

We therefore believe this study will be of importance to readers of Marine Policy and suitable for peer review. If you have any questions please do not hesitate to contact myself (lauren.mattingley@googlemail.com) or my co-authors.

Yours sincerely,

Lauren Mattingley MSc.

On behalf of Beth E. Scott ( (sevvandi_jayakody@yahoo.com) 
School of Biological Sciences,

University of Aberdeen,

Tillydrone Avenue,

Aberdeen

AB24 2TZ

$16^{\text {th }}$ February 2016

Dear Mr Smith,

Firstly we would like to thank all the reviewers and editors for their time and effort in making this manuscript meaningful and focused. All the formatting requests have been accounted for and the reviewers' comments addressed. The table below shows each point made by the reviewers and how the manuscript has been altered as a consequence.

\begin{tabular}{|c|c|}
\hline Reviewers Comment & Alterations/Response \\
\hline $\begin{array}{l}\text { At the moment the manuscript does not } \\
\text { mention MPAs and I wondered, given the } \\
\text { outcome, is a management plan for a specific } \\
\text { species whether reference to MPA should be } \\
\text { included, as this is effectively the outcome? }\end{array}$ & $\begin{array}{l}\text { Comment incorporated into MS } \\
\text { This research and paper is not about creating an MPA, } \\
\text { but about the process of ecosystem-based } \\
\text { management. MPAs are distinguished in the legal } \\
\text { system as a completely different management tool. } \\
\text { However, to enforce the differences and similarities } \\
\text { between the two approaches and avoid confusion to } \\
\text { readers I have added: } \\
\text { Introduction Paragraph 1, lines 4-9: } \\
\text { Although Marine Protected Areas (MPA's) have become } \\
\text { a popularised solution for fisheries and ecosystem } \\
\text { management problems, they are now considered one of } \\
\text { many tools in the management toolbox [3]. MPA's can } \\
\text { contribute towards ecosystem-based management } \\
\text { goals, but EAFM takes spatial planning concepts further } \\
\text { by focusing more on stakeholder participation and } \\
\text { taking into account socioeconomic needs and realities. } \\
\text { It has been suggested that better synergies between } \\
\text { these two approaches will greatly benefit marine } \\
\text { conservation attempts [4]. }\end{array}$ \\
\hline $\begin{array}{l}\text { Abstract: - 7th line, as it currently reads it } \\
\text { implies the dolphins themselves are being } \\
\text { fished. It could benefit from re-phrasing. }\end{array}$ & $\begin{array}{l}\text { Comment incorporated into MS } \\
\text { Abstract lines 6/7: } \\
\text {... where there is a population of spinner dolphins that } \\
\text { the local community are especially dependent on } \\
\text { through tuna-dolphin association fishing and dolphin- } \\
\text { watching tourism. }\end{array}$ \\
\hline $\begin{array}{l}\text { Page } 3 \text { Table } 1 \text {-' tuna target species... non- } \\
\text { target fishermen due fishing using tuna- } \\
\text { dolphin associations.' I think the word 'to' is } \\
\text { missing. }\end{array}$ & $\begin{array}{l}\text { Comment incorporated into MS } \\
\text { The word 'to' has been inserted here. }\end{array}$ \\
\hline Figure 6 - did not display in the copy I received & Comment incorporated into MS \\
\hline
\end{tabular}




\begin{tabular}{|c|c|}
\hline (Ed. - check legibiity) & $\begin{array}{l}\text { We have resized and reformatted the JPEG file, so it } \\
\text { should display correctly now. }\end{array}$ \\
\hline $\begin{array}{l}\text { Discussion: First paragraph: Although I agree } \\
\text { that the manuscript gives an excellent } \\
\text { example of effective community engagement } \\
\text { to create a management strategy the study } \\
\text { has tackled only one issue, the protection of } \\
\text { spinner dolphins, so comparison with other } \\
\text { MSP projects and timescales is difficult. The } \\
\text { study did however gain rapid buy-in to the } \\
\text { process. The USA example should be given a } \\
\text { reference if possible, even if to a website. I } \\
\text { think this paragraph could be re-phrased, still } \\
\text { highlighting the achievements of this study } \\
\text { and how it could be applied elsewhere. }\end{array}$ & $\begin{array}{l}\text { Comment incorporated into MS } \\
\text { We rephrased the paragraph and added a reference as } \\
\text { requested. } \\
\text { Discussion paragraph 1: } \\
\text { This study has shown that with a small amount of } \\
\text { interaction at grass roots level, marine spatial planning } \\
\text { and EAFM implementation can occur quite rapidly. } \\
\text { However, comparing this work to other MSP projects } \\
\text { and timescales is challenging, as other examples of } \\
\text { such a rapid creation of a marine spatial plan are } \\
\text { typically on much larger scales. The California Marine } \\
\text { Life Protection Act MPA network was created in a } \\
\text { relatively short timeline of just over a year [17]. The key } \\
\text { to the success of this project was the same as in the } \\
\text { current study: extensive stakeholder participation that } \\
\text { resulted in educated user groups and highly motivated } \\
\text { and involved stakeholders that are more likely to } \\
\text { support and abide by the rules that they helped } \\
\text { establish [18]. Although the current study represents a } \\
\text { much simpler system with fewer sectors involved than } \\
\text { the California example, it is of no less importance to the } \\
\text { local economy. While this work appears to } \\
\text { predominantly focus on a single issue - the } \\
\text { conservation of spinner dolphins - a crucial part of } \\
\text { ensuring viability of the dolphin population is } \\
\text { maintaining the ecosystem they depend on. If } \\
\text { successfully implemented and supported over a suitable } \\
\text { timescale, this EAFM plan has the potential to improve } \\
\text { the overall health of the Kalpitiya marine system and its } \\
\text { connecting areas as well as sustaining the spinner } \\
\text { dolphins. }\end{array}$ \\
\hline
\end{tabular}

We hope that all the valuable comments have now being adequately addressed in the revised manuscript and we would be very glad if you could consider the revised manuscript for possible publication in Marine Policy. If you have any issues with the alterations please do not hesitate to contact myself (lauren.mattingley@gmail.com) or my co-authors.

Yours sincerely,

Lauren Mattingley MSc.

On behalf of Beth E. Scott (b.e.scott@abdn.ac.uk) and Sevvandi Jayakody (sevvandi_jayakody@yahoo.com) 
Exploring the applicability of biological and socioeconomic tools in developing EAFM plans for data absent areas: Spinner dolphin EAFM for Kalpitiya, Sri Lanka

\author{
Lauren Mattingley ${ }^{1 *}$, Sevvandi Jayakody ${ }^{2}$, Beth E. Scott ${ }^{1}$ \\ ${ }^{1}$ Institute of Biological and Environmental Sciences, Zoology Building, University of Aberdeen, Aberdeen AB24 2TZ, UK \\ 2 Department of Aquaculture \& Fisheries, Wayamba University of Sri Lanka, Makandura, Gonawila, Sri Lanka \\ ${ }^{*}$ Corresponding author.
}

Email addresses of co-authors: sevvandi jayakody@yahoo.com; b.e.scott@abdn.ac.uk

Corresponding Author

Lauren Mattingley, MSc

lauren.mattingley@googlemail.com 
- The successful applicability of the EAFM approach for a data poor area is provided

- The benefit of using questionnaires and GIS analyses as part of EAFM scoping is shown

- A full stakeholder agreed spinner dolphin centred EAFM plan for Kalpitiya is proposed 


\title{
Exploring the applicability of biological and socioeconomic tools in developing EAFM plans for data absent areas: Spinner dolphin EAFM for Kalpitiya, Sri Lanka
}

\begin{abstract}
The ecosystem approach to fisheries management (EAFM) methodology is currently considered the preferred option for long-term sustainability of fisheries and ecosystem services and is widely popularised. Manuals, guidelines and training have been given to many nations, but the actual existence and execution of an EAFM plan is rare. The applicability and relevance of biological and socioeconomic tools to follow EAFM planning guidelines in a data absent area were explored in Kalpitiya, northwest Sri Lanka, where there is a population of spinner dolphins that the local community are especially dependent on through tuna-dolphin association fishing and dolphin-watching tourism. This paper provides background to the design and collection of information leading to the formulation of an EAFM management plan. Scoping and the determination of a fishery management area were completed through stakeholder consultations using a combination of interviewer-administered questionnaires, interviews, meetings, dolphin distribution data and existing management plans. Threats and stakeholder prioritisation were compiled and the final agreed fisheries management area covers a total area of $2445 \mathrm{~km}^{2}$ adjacent to the Kalpitiya peninsula. The completed EAFM plan contains 4 goals, 16 actions and 72 sub-actions agreed by stakeholders. It was concluded that both willingness of higher level stakeholders responsible for implementing regulations and working with grass-root level stakeholders are critical in developing a realistic and implementable EAFM plan. This work also highlights how data absence should not remain the bottleneck that hinders moving forward with EAFM approaches.
\end{abstract}

\section{Keywords}

Ecosystem approach to fisheries management, Spinner dolphin, Stenella longirostris, Stakeholder engagement, Gulf of Mannar

\section{Introduction}

The ecosystem approach to fisheries management (EAFM) recognises that a management system that ignores social aspects of fisheries is bound to fail [1]. The EAFM framework is a step-wise, hierarchical, threat-based approach, where consultation of all relevant stakeholders involved is critical throughout all steps [2]. Although Marine Protected Areas (MPA's) have become a popularised solution for fisheries and ecosystem management problems, they are now considered one of many tools in the management toolbox [3]. MPA's can contribute towards ecosystem-based management goals, but EAFM takes spatial planning concepts further by focusing more on stakeholder participation and taking into account socioeconomic needs and realities. It has been suggested that better synergies between these two approaches will greatly benefit marine conservation attempts [4]. The overall aim of EAFM is to sustain healthy marine ecosystems and the fisheries they support, therefore ecosystem components and interactions that the species depend on, such as habitat, predators and prey are all considered [5]. Opportunities for EAFM execution have been scarce and challenges in developing EAFM plans has resulted in rare implementation despite the availability of resources and training given throughout coastal countries [6].

Many of Asia's prime fishing grounds are also ecologically important systems, and years of unsustainable fishing has resulted in depletion of biodiversity directly affecting the species as well as income to local people [7]. Additionally, emerging tourism in coastal and offshore tropical seas is putting further pressure on Asia's marine systems, particularly in Sri Lanka [8]. In Kalpitiya, situated in the northwest of the country, there is a prevalent coastal population of spinner dolphins. These dolphins specifically utilise the waters parallel to the Kalpitiya peninsula and throughout the Gulf of Mannar. Dolphins are typically top-predators within their ecosystems and have a fundamental influence on marine community structure; therefore maintaining populations of dolphins is critical to maintain healthy, productive ecosystems [9]. Modern mechanised fishing methods such as trawls, purse seines and gillnets pose the biggest threat to dolphins [10][11][12] and all these fishing mechanisms are exercised in Kalpitiya. Moreover, whale and dolphin watching has recently become a major activity in the region from November to April. As fishing activities have already affected this dolphin population it is critical that new tourism expansion does not cause the local population to dwindle further. Damage from recent uncontrolled dolphin-watching tourism expansion and gillnet by-catch has already been noted in similar systems [13][14]. 
As the stakeholders of the Kalpitiya marine system and their expectations are diverse, in order to ensure ecological and human wellbeing, the establishment of good governance is essential for Kalpitiya. Hence, a study was conducted using various biological and socioeconomic tools to collect the baseline data that

would allow completion of the steps indicated in EAFM manuals to formulate a spinner dolphin centred EAFM plan. The main aims were to define a realistic but effective area to be managed, outline the key stakeholders and highlight the key threats in the proposed management area and to present all the collected information to the main stakeholders to finalise goals and actions for an implementable EAFM plan. The applicability and validity of the tools used to meet these aims were then evaluated and recommendations made for future EAFM plans in data deficient areas.

\section{Methodology}

2.1. Determination of the spinner dolphin FMU (fisheries management unit)

The EAFM procedure followed was based on the guidelines defined in the Essential EAFM Handbook: Ecosystem Approach to Fisheries Management Training Course Version 1 [15], accessible through www.boblme.org. For an EAFM plan to be successful, a clear statement of the area to be managed is required, called the fisheries management unit (FMU).

To determine the FMU three transect surveys were conducted on a local ecotourism vessel between the hours of 9:00 am and 2:00pm covering a total distance of 147.78km. A handheld GPS (Garmin eTrex Venture) was used to take GPS recordings every 5 minutes along the transect. In addition to the positional data, other variables such as time, number of spinner dolphins observed, behaviour of the dolphins, sea state (Beaufort scale) and sightability were also recorded. Additional positional data for spinner dolphins in Sri Lanka were obtained from Martenstyne (2013) [16]. This data was a collection of GPS data from scientific research, tourism operators and personal recordings from 1972-2013. To investigate whether the distribution of dolphin sightings showed a consistent pattern, the density of dolphin sightings per square kilometre was calculated and plotted using a kernel density method (ArcMap version 10.2.1 ESRI Inc.). This analysis was performed on the compiled GPS sightings data only around the northwest of Sri Lanka.

Two separate questionnaires, one for fishermen and one for tourism operators with questions regarding their practices, experience and opinions on various features of the Kalpitiyan spinner dolphin population, plus their attitude towards current fishing practices and existing management were performed in the initial stages of the study. The first part of the questionnaire was given with a map of the coastline comprising a $5 \mathrm{~km}^{2}$ grid over the water to give the interviewees an idea of scale. Questions prompted the interviewees to draw shapes on the map that represented their impression of spinner dolphin core habitat. A total of 25 fishermen and 14 tourism operators were interviewed. The impressions of dolphin core area drawn on the questionnaire maps were recreated spatially (ArcMap version 10.2.1 ESRI Inc.). A polygon comprising this area to scale was created for each questionnaire. A $2 \mathrm{~km}^{2}$ polygon grid was overlaid onto the area map that covered all of the drawn polygons for fishermen and tourism operators separately. Each polygon square in the grid was manually assigned a 'prevalence index' value, which was the total number of questionnaire polygons overlapping that square. A polygon was counted as overlapping if it covered half the square or greater. The squares were analysed spatially using Getis-Ord $\mathrm{Gi}^{*}$ analysis to determine where there were hotspots of perceived dolphin habitat. The Getis-Ord Gi* analysis was chosen specifically as it can identify spatially explicit areas of high use based on a specific test criteria. Hotspots are clusters of grid squares with Z-scores that are statistically significant $(p<0.05)$, and low $Z$-score clusters of grid squares are cold spots that have no statistical significance $(p>0.05)$.

Results from the questionnaires concerning hotspots and the high sightings density areas were compared to deduce an ideal FMU. In determining the realistic FMU, existing administrative boundaries and boundaries of hotspots created from GPS sighting data, fishermen and tour operators experience data were considered. This ideal FMU was reduced to form a realistic FMU that would be logistically possible for local people to manage yet still incorporated a high percentage of the questionnaire hotspots and high sightings density areas (Fig. 3).

Areas of each drawn dolphin habitat polygon were calculated in $\mathrm{km}^{2}$ and generalised linear models (GLM) were applied to see if any background characteristics of the fishermen or tourism operators interviewed were significantly impacting their perceptions of dolphin core area size. Dolphin area was square root transformed. Six fisherman and 3 tourist operator explanatory variables (Table 1) were used after verifying a lack of collinearity through bivariate plots for all possible pairs of variables. A stepwise 
selection procedure was used to determine which combination of variables had the most explanatory power. The model with the lowest AIC value was selected as the model with the best predictive power, however models within $2 \triangle \mathrm{AIC}$ of the 'best' model were still explored. Data were analysed using the software R Version 3.2.0.

Table 1 here;

\subsection{Identifying threats to the system in comparison to attitudes and willingness of stakeholders} The second part of the questionnaire aimed to highlight what the fishermen and tourism operators believed were the biggest threats to the dolphin population and assess their willingness to change their behaviour for spinner dolphin conservation. Questions either used a Likert-scale answering system that ranged from 'Strongly Disagree' to 'Strongly Agree' or a categorical answering system, such as 'Yes' or 'No'.

Further interviews with additional stakeholders were also conducted both in person and over the phone. Those interviewed included an environmental lawyer, an NGO leader, a marine conservationist, a hotel owner and officers from both the Department of Wildlife Conservation and the Department of Coast Conservation. These stakeholders were asked the same three questions: Who do you believe are the key stakeholders, what are the main threats in the area and why has management so far been unsuccessful? Additionally, all relevant government agencies and NGO/INGO were briefed through a common letter about the EAFM process taking place, the aims of the work and their role in ensuring its success.

The willingness of fishermen and tourist operators to change their existing behaviour was explored using Likert scale questions. Four Likert scale questions were collapsed to create binomial response variables, with $0=$ not willing to change and $1=$ willing to change. Neutral answers were added into the 'Yes' category, with the assumption that they could be persuaded to a 'yes'. GLMs with a binomial error structure and a logit-link function were used to relate the willingness of fishermen and tourist operators to change to the same explanatory variables used in the perception analyses (Table 1). Data were analysed using the software R Version 3.2.0.

\subsection{Stakeholder workshop and EAFM plan development}

An EAFM workshop was planned and held at the Kalpitiya visitor centre on the $7^{\text {th }}$ July 2015; stakeholders from the local community and the government (Department of Wildlife Conservation, Coast Conservation Department and Department of Fisheries) were invited. The workshop was conducted in four sections (Table 2). Prior to the workshop, the compliance of the plan to international and national policies relevant to species management, ecosystem management, community development was verified. Additionally provisions under different acts and ordinances of the main stakeholder government agencies to implement co-management were also checked.

Table 2 here;

A preliminary EAFM plan was created prior to the workshop based on the collected data with stakeholder consultation. The focus of the workshop was to present this plan to all stakeholders and amend, append and verify the implementation with the existing governance structure. Alterations to the plan were made accordingly with the input from the stakeholders. A stakeholder analysis exercise was conducted in a Venn diagram format to visualise the current status of relationships between stakeholders and highlight where communication needs improving (Fig. 6). Threats and stakeholder importance were also assembled into $2^{\star} 2$ matrices (Fig. 4 and 5).

\section{Results}

\subsection{FMU determination results}

A total of 7 spinner dolphin sightings were made on the boat surveys, where pod size varied from 30 to 500 (Fig. 1A). A total of 204 spinner dolphin GPS points were obtained from Martenstyne (2013) [16](Fig. 1B). Plotting resulted in a large cluster in the northwest of the country (92 sightings). The kernel density plot showed that the greatest density of sightings was $0.45-0.5$ spinner dolphin sightings per square kilometre and the region that contained this high density was roughly $5 \mathrm{~km}$ west from the village of Illamthadi. This high-density spot was $5.2 \mathrm{~km}$ long and $3.6 \mathrm{~km}$ wide. Sightings density was also high (0.30.35 sightings per square kilometre) about $5 \mathrm{~km}$ west from Thalawila. About $4.3 \mathrm{~km}$ west of Kandakuliya, 
sightings density was still substantial (0.25-0.3 sightings per $\left.\mathrm{km}^{2}\right)$. A second separate high-density spot was also present about $11 \mathrm{~km}$ west of Rodhapadu with 0.35-0.4 spinner dolphin sightings per square $\mathrm{km}$ (Fig. 1C).

Figure 1 here;

All fishers were male and on average 36 years old $( \pm 10.99)$ with 21 years $( \pm 9.90)$ fishing experience. The majority of fishermen fished no further than $40 \mathrm{~km}$ from the coast, no fisher used a vessel over $15 \mathrm{~m}$ in length and the most common gear type used ( $40 \%$ of interviewees) was a combination of lines and nets. Almost half of the fishermen targeted tuna (48\%) whereas the others were all non-specialists. Fishermen interviewed were from six different villages and just under half $(48 \%)$ of them migrated during the off-season (Table 3). The migratory fishermen either moved to Trincomalee in the East or switched to the Puttalam lagoon fishery. All vessels used for tourism activities were under $10 \mathrm{~m}$. Over half $(57 \%)$ of the operators provided dolphin watching, scuba diving and other additional services.

Table 3 here;

Spinner dolphins are a regularly seen species by both fishermen (72\%) and tourist operators (93\%). The mean estimate of pod size from tourist operators was over twice as large as the fishermen estimate (8397 individuals $( \pm 12853.91)$ and 3628 individuals $( \pm 5275.38)$ respectively). There was strong opinion that the spinner dolphin population was non-migratory (79\% of fishermen and $93 \%$ of tourist operators agreed) however there was also belief that the population was not constant all year round $(70 \%$ of fishermen and $64 \%$ of tourist operators). The tourist operators described higher abundances of dolphins between December and March and the majority of fishermen said the highest abundances occurred between October and February (Table 3 and 4). Both fishermen and tourist operators agreed 100\% that spinner dolphins are not found in Puttalam lagoon, stating that only humpback dolphins (Sousa chinensis) are seen there.

Table 4 here;

The dolphin core areas perceived by the fishermen ranged from $125.7 \mathrm{~km}^{2}$ to $10295.4 \mathrm{~km}^{2}$. The total area of the statistically significant hotspot was $3712 \mathrm{~km}^{2}$, stretching $106 \mathrm{~km}$ at the longest point and $46 \mathrm{~km}$ at the widest point (Fig. 2A). The dolphin core areas perceived by the tourism operators ranged from the smallest estimate of $116.45 \mathrm{~km}^{2}$ to the largest estimate of $5774.22 \mathrm{~km}^{2}$. The area of the statistically significant hotspot was $972 \mathrm{~km}^{2}, 2740 \mathrm{~km}^{2}$ smaller than the fisherman hotspot (Fig. 2B). The fishermen perceived hotspot was $9.5 \mathrm{~km}$ west from the coast at Kandakuliya and spanned approximately between Simatodwawa in Puttalam district and Cheddiyarkandal in Mannar district (Fig. 2A). The tourist operator hotspot spanned $76.04 \mathrm{~km}$ at the longest point and $18 \mathrm{~km}$ at the widest point. The hotspot was $2.87 \mathrm{~km}$ west from the coast of Kandakuliya and stretched between Kudiramalai Point and Sinnapaduwa in the south of Puttalam district (Fig. 2B).

Figure 2 here;

Stepwise GLM model selection to identify which characteristics of fishermen best explained the variation in their expectation of the size of the area that the dolphins occupied indicated that the inclusion of vessel size and whether fisherman annually migrated to other fishing grounds and maximum distance fishing from coast produced the optimal model with the best predictive power and lowest AIC $(A I C=207.01)$. However, using backwards stepwise model selection and dropping vessel size produced a model with a negligible increase in AIC $(<2)$, indicating that vessel size explains a small amount of the variation. So those fishermen that fish farther from the coast perceive the dolphin area as larger and those who migrate perceive the dolphin area as smaller. When fishermen didn't migrate larger dolphin core areas were perceived. Due to the smaller sample size of questionnaires for the tour operators, no viable model could be found to explain the variance in perceived dolphin area size.

The ideal FMU covered a total of $6681.8 \mathrm{~km}^{2}$ and incorporates $100 \%$ of all the previously obtained hotspots. The realistic FMU covered a total area of $2445 \mathrm{~km}^{2}$ and is $72.8 \mathrm{~km}$ long by $33.6 \mathrm{~km}$ wide (Fig. 3). The realistic FMU overlapped with both the Bar Reef marine protected area administered by Department of Wildlife Conservation (47\%) and the special area of management administered by Department of Coast conservation (21\%). Within the realistic FMU, 68\% $\left(1667.8 \mathrm{~km}^{2}\right)$ and $83 \%\left(805 \mathrm{~km}^{2}\right)$ of the 
fishermen and tourism operator questionnaire spinner dolphin core area hotspot was included respectively. The high-density sightings areas from the GPS data were also $100 \%$ included within the realistic FMU.

Figure 3 here;

\subsection{Threat identification and stakeholder willingness results}

Illegal fishing was identified as the main threat to the area. Overfishing and disturbances from tourism were also declared as key threats. Transboundary issues were also emphasised, specifically bycatch threats from large-scale fishers entering the region and using industrial size gillnets. All interviewees agreed existing policies were effective but problems occurred due to inefficient implementation. For example, police not receiving enough political backing to remand fishers caught using illegal fishing methods. Reliance on anecdotal data and a deficiency of reliable biological estimates were also stated as a management issue, specifically a lack of communication between scientists and governmental departments.

All tourist operators and $96 \%$ of fishermen believed that spinner dolphin conservation is beneficial, $96 \%$ of fishermen also strongly disagreed that spinner dolphins reduce their fish stocks through predation and $96 \%$ of fishermen strongly agreed spinner dolphins were a useful indicator for good fishing spots.

Fishermen and tourist operators agreed ( $84 \%$ and $93 \%$ respectively) that there were regulations in place to protect dolphins from tourism and fishing threats. The majority of fishermen (92\%) stated serious consequences occurred when these regulations were disobeyed whereas only $64 \%$ of tourism operators agreed with this.

The majority of fishermen and tourist operators did not believe that dolphin-watching tourism disturbs spinner dolphins ( $44 \%$ of fishermen disagreed and $50 \%$ of tourism operators strongly disagreed). There was a varied response to whether high levels of tourism in the area are a threat to the dolphins, with $36 \%$ of tourism operators disagreeing but $36 \%$ also agreeing. A high percentage of fishermen disagreed $(72 \%)$ that tourism was a threat. Most of the tourism operators (43\%) strongly agreed increasing nonnatural flotsam was a threat to the dolphin population whereas $40 \%$ of fishermen disagreed that it was a problem. Fishermen agreed $(52 \%)$ that Indian trawlers were a threat to the area, but also strongly agreed (88\%) that illegal dynamite fishing was a big issue.

After collapsing the Likert scale answers from the questionnaires to create the four binomial willingness response variables, the percentages of willingness and unwillingness were calculated for each (Table 5).

Table 5 here;

GLMs with a binomial error structure and a logit-link function were used to relate the willingness of fishermen and tourist operators to change to the same explanatory variables used in the perception analyses (Table 1). As Tourism operators were $100 \%$ willing to conform to speed limits and distance buffers for spinner dolphin conservation (response variable 3: Willingness to conform to vessel speed limits and distance buffers for spinner dolphin conservation, Table 5) only 3 GLM models were tested to explore if the characteristics of fishermen or tour operators explain the variation in their degree of wiliness to change behaviours. For response variable 1 (Willingness to modify fishing gear to improve spinner dolphin conservation, Table 5) a valid model could not be conclusively defined due to a lack of deviation within the data. A valid model also could not be found for response variable 4 (Willingness to avoid operating in specific areas to provide rest refuges in dolphin core habitat, Table 5), however years of experience explained most of the variation. There was a positive relationship with willingness to avoid key areas and experience, suggesting that greater experienced operators are more willing to provide rest refuges from tourism in dolphin core areas. However none of these relationships were significant, most likely due to the small sample size of questionnaires.

The only analysis that produced a valid model was for Fishermen and the response variable 2 (Willingness to fish in different areas to improve spinner dolphin conservation, Table 5). Inclusion of gear type alone produced the best model $(\mathrm{AIC}=23.25)$ with a significant difference $(\mathrm{p}=0.04)$ between gear type 1 (lines) and gear type 2 (nets) and between gear type 2 and gear type 3 (the use of both lines and nets, $p=0.02$ ). Nets had a positive coefficient of 3.18 when compared to lines, and a positive coefficient of 3.58 when compared to fishermen who use both gear types. As lines and nets and lines 
alone had negative coefficients, this suggests that fishermen who use nets are the most willing to avoid fishing in dolphin core areas.

\subsection{The EAFM workshop results and final plan}

From the outcome of the EAFM workshop the $2 * 2$ matrix analysis of issues and threats indicated illegal fishing, disturbance from tourists swimming and diving with dolphins, non-natural materials in the system, fishermen barging through pods, new mega-scale tourist operators, gillnet bycatch and lack of transboundary fishing regulations and communication as the most significant and high impact issues and threats to the system (Fig. 4).

Figure 4 here;

Threats were also categorised as socio-economic, ecological or governance based (Table 6).

Table 6 here;

The stakeholder matrix indicated that the Department of Wildlife Conservation, Department of Fisheries, Coast Conservation Department, Department of Forest, Provincial Environmental Authority, police, navy, NGO's, NARA, MEPA, Divisional Secretariat, local tour operators and fishermen are the most influential and important stakeholders (Fig. 5). The Venn diagram representing existing relationships of stakeholders showed that effort needs to be put into bridging communication gaps between MEPA, policy makers, the Forest Department, the tourist board, the new mega-scale tour operators, the provincial council and provincial environmental authority (Fig. 6).

Figure 5 here;

Figure 6 here;

The chosen vision for the proposed FMU for next 8 years was "A thriving population of spinner dolphins in a healthy environment at Kalpitiya ". The agreed EAFM plan had four goals:

1) The good governance for Kalpitiya ecosystem and spinner dolphin management is established

2) The fisheries and tourism associated with the spinner dolphin population are sustained to ensure the security of local people's livelihoods

3) The Kalpitiyan marine system is restored for the betterment of both spinner dolphins and the local communities

\section{4) A natural balance of spinner dolphins in the Kalpitiya ecosystem is established}

As per the guidelines of EAFM, objectives, actions and sub actions were developed. Baselines of indicators of change and their targets were also decided on. Approval was consensual for all presented actions and sub-actions; these actions were then allocated under the four goals (some actions crossed over and were included for multiple goals). The finalised list of 4 goals, 16 actions and 72 sub-actions made up the bulk of the official EAFM plan. Suitable initiation times, benchmarks and indicators were added into this plan post workshop. For full details of the EAFM plan see supplementary material.

\section{Discussion}

This study has shown that with a small amount of interaction at grass roots level, marine spatial planning and EAFM implementation can occur quite rapidly. However, comparing this work to other MSP projects and timescales is challenging, as other examples of such a rapid creation of a marine spatial plan are typically on much larger scales. The California Marine Life Protection Act MPA network was created in a relatively short timeline of just over a year [17]. The key to the success of this project was the same as in the current study: extensive stakeholder participation that resulted in educated user groups and highly motivated and involved stakeholders that are more likely to support and abide by the rules that they helped establish [18]. Although the current study represents a much simpler system with fewer sectors involved than the California example, it is of no less importance to the local economy. While this work appears to predominantly focus on a single issue - the conservation of spinner dolphins - a crucial part 
of ensuring viability of the dolphin population is maintaining the ecosystem they depend on. If successfully implemented and supported over a suitable timescale, this EAFM plan has the potential to improve the overall health of the Kalpitiya marine system and its connecting areas as well as sustaining

\begin{abstract}
In this study, using questionnaires as a tool in the EAFM planning process had multiple significant advantages. Not only was urgently needed background information collected rapidly and effectively, but much needed connections between grass-root level stakeholders and management were formed. Ownership was created through questionnaire involvement, increasing understanding, awareness and the likelihood of compliance to the EAFM plan. Following up the questionnaires and interviews with the EAFM stakeholder workshop consolidated with the local people that their perceptions were valued and that they were an integral part of the process. The stakeholder workshop also improved links between stakeholders, as people from all different backgrounds that typically would not meet were able to communicate, empathise and come to the realisation that the majority of them had common interests.
\end{abstract}

Geographic Information System software played a critical role in the designation of the fisheries management area in this study. It provided an easily interpretable visual representation of where GPS data indicated the main spinner dolphin habitat was as well the location of the spinner dolphin core area as perceived by those who knew the area best. All members of the stakeholder workshop in Kalpitiya responded well to the maps and were able to follow the 'hotspot' concepts with ease. The results from this work highlight the speed and effectiveness of using GIS based analyses to decide an effective management area and how it can be an integral tool in the process of FMU designation for future EAFM plans. ArcMap was used to generate the maps in this work, however the same results could be achieved with free equivalent software packages to minimise cost. Even when data on species distributions and habitat usage is minimal, adoption of some form of scientific approach to area demarcation is emphasised here against hypothetical area demarcation based on local knowledge that may or may not indicate the true distribution of the species.

The biggest risk factor in proceeding with the Kalpitiyan spinner dolphin EAFM is lack of engagement by higher government levels. Many government stakeholders did not turn up to the stakeholder workshop after multiple invitations. This may be attributed to a lack of understanding regarding the connectedness of the Kalpitiya marine system, resulting in a detachment to the EAFM plan. Without higher-level government backing international fishing activity will remain unregulated. Ignoring transboundary fishing threats leaves the system vulnerable to overexploitation [19], potentially hindering efforts made by other stakeholders, particularly those at community level. Also, current studies have revealed that most acts and ordinances (e.g. Fisheries and Aquatic Resources Amendment Act No.35 of 2013), have provisions for co-management, hence embracing EAFM concepts is feasible. Top down management of natural resources has failed, hence empowering the agencies to co-management is timely in Asia [20].

One of the main concerns in EAFM planning is implementation without sufficient data. Data deficiency or absence has the potential to discourage environmental managers, as it prevents them making properly informed decisions about the system in question [21]. This study has shown that having all possible data is not a necessity; simply having enough data to input into a GIS type software to make representative maps and getting a true idea of the predominant issues threatening a system through mechanisms such as questionnaires is sufficient enough to instigate preliminary actions. For Kalpitiya, obtaining stock assessments such as CPUE and more biological spinner dolphin data will be beneficial to measure the difference the plan is making and to refine it accordingly for continual improvement. This is addressed by the developed EAFM as a management action.

The Kalpitiya spinner dolphin EAFM was created in a three-month timeframe and it has given stakeholders a purpose by designating everyone with a role. This helped to bring the plan to life, making it more likely to be implemented than by simply attempting to bring in top-down oriented regulation. This study has shown that progress that can be made in a very short time frame by using rather simple and well tested techniques such as questionnaires, mapping and workshops that motivate the involvement of key stakeholders. It also confirms that the approaches given in EAFM planning manuals are applicable and implementable even in data-deficient regions. This is an EAFM plan that has the backing of the majority of the local fishing and tourism industry and stands ready to be implemented. 


\section{Acknowledgements}

University of Aberdeen, UK and Bay of Bengal Large Marine Ecosystems (BOBLME) project are acknowledged for partial funding of this research.

\section{References}

[1] E. Pikitch, E. Santora, A. Babcock, A. Bakun, Ecosystem-based fishery management, Science (80-. ). 305 (2004) 346-347. doi:10.1126/science.1098222.

[2] W.J. Fletcher, G. Bianchi, H.R. Skjoldal, The ecosystem approach to fisheries, CABI, Wallingford, 2008. doi:10.1079/9781845934149.0000.

[3] R. Pomeroy, Marine Protected Areas: an Ecosystem-Based Fisheries Management Tool, Wrack Lines. (2003).

[4] B.S. Halpern, S.E. Lester, K.L. McLeod, Placing marine protected areas onto the ecosystem-based management seascape., Proc. Natl. Acad. Sci. U. S. A. 107 (2010) 18312-7. doi:10.1073/pnas.0908503107.

[5] S. Garcia, K. Cochrane, Ecosystem approach to fisheries: a review of implementation guidelines, ICES J. Mar. Sci. 62 (2005) 311-318. doi:10.1016/j.icesjms.2004.12.003.

[6] M. Skern-Mauritzen, G. Ottersen, N.O. Handegard, G. Huse, G.E. Dingsør, N.C. Stenseth, et al., Ecosystem processes are rarely included in tactical fisheries management, Fish Fish. (2015). doi:10.1111/faf.12111.

[7] I.C. Stobutzki, G.T. Silvestre, A. Abu Talib, A. Krongprom, M. Supongpan, P. Khemakorn, et al., Decline of demersal coastal fisheries resources in three developing Asian countries, Fish. Res. 78 (2006) 130-142. doi:10.1016/j.fishres.2006.02.004.

[8] R. Bandara, The Practice of Ecotourism in Sri Lanka: An Assessment of Operator Compliance towards International Ecotourism Guidelines, South Asia Econ. J. 10 (2009) 471-492. doi:10.1177/139156140901000209.

[9] R.P. Kumarran, Cetaceans and cetacean research in India, J. Cetacean Res. Manag. 12 (2012) 159-172.

[10] E.F. Edwards, Fishery effects on dolphins targeted by tuna purse-seiners in the Eastern Tropical Pacific Ocean, Int. J. Comp. Psychol. 20 (2007) 217-227.

[11] K.T. Fitzgerald, Longline fishing (How What You Don't Know Can Hurt You), Top. Companion Anim. Med. 28 (2013) 151-162. doi:10.1053/j.tcam.2013.09.006.

[12] R. Reeves, K. McClellan, T. Werner, Marine mammal bycatch in gillnet and other entangling net fisheries, 1990 to 2011, Endanger. Species Res. 20 (2013) 71-97. doi:10.3354/esr00481.

[13] O. Amir, P. Berggren, N. Jiddawi, The Incidental Catch of Dolphins in Gillnet Fisheries in Zanzibar, Tanzania, West. Indian Ocean J. Mar. Sci. 1 (2002) 155-162.

[14] F. Christiansen, D. Lusseau, E. Stensland, P. Berggren, Effects of tourist boats on the behaviour of IndoPacific bottlenose dolphins off the south coast of Zanzibar, Endanger. Species Res. 11 (2010) 91-99. doi:10.3354/esr00265. 
[15] D. Staples, R. Brainard, S. Capezzuoli, S. Funge-Smith, C. Grose, A. Heenan, et al., Essential EAFM. Ecosystem Approach to Fisheries Management Training Course. Volume 1 - For Trainees, FAO Regional Office for Asia and the Pacific, Bangkok, Thailand, RAP Publication 2014/13, 2014.

[16] H. Martenstyne, Sri Lanka Marine Mammal Records: a compilation of historical and contemporary records relating to marine mammal occurrence in Sri Lanka and adjacent waters, 1st ed., Centre for Research on Indian Ocean Marine Mammals (CRIOMM) c/o Indian Ocean Marine Affairs Co-operation (IOMAC), 2013.

[17] C.J. Klein, A. Chan, L. Kircher, A.J. Cundiff, N. Gardner, Y. Hrovat, et al., Striking a balance between biodiversity conservation and socioeconomic viability in the design of marine protected areas., Conserv. Biol. 22 (2008) 691-700. doi:10.1111/j.1523-1739.2008.00896.x.

[18] M. Gleason, S. McCreary, M. Miller-Henson, J. Ugoretz, E. Fox, M. Merrifield, et al., Science-based and stakeholder-driven marine protected area network planning: A successful case study from north central California, Ocean Coast. Manag. 53 (2010) 52-68. doi:10.1016/j.ocecoaman.2009.12.001.

[19] L.E. Visser, D.S. Adhuri, Fishing in, fishing out: transboundary issues and the territorialization of blue space, Asia-Pacific Forum. 36 (2007) 112-145.

[20] F. Zagonari, Integrated coastal management: Top-down vs. community-based approaches, J. Environ. Manage. 88 (2008) 796-804. doi:10.1016/j.jenvman.2007.04.014.

[21] N.C. Ban, G.J.A. Hansen, M. Jones, A.C.J. Vincent, Systematic marine conservation planning in data-poor regions: Socioeconomic data is essential, Mar. Policy. 33 (2009) 794-800. doi:10.1016/j.marpol.2009.02.011. 


\section{Figure}

Click here to download high resolution image

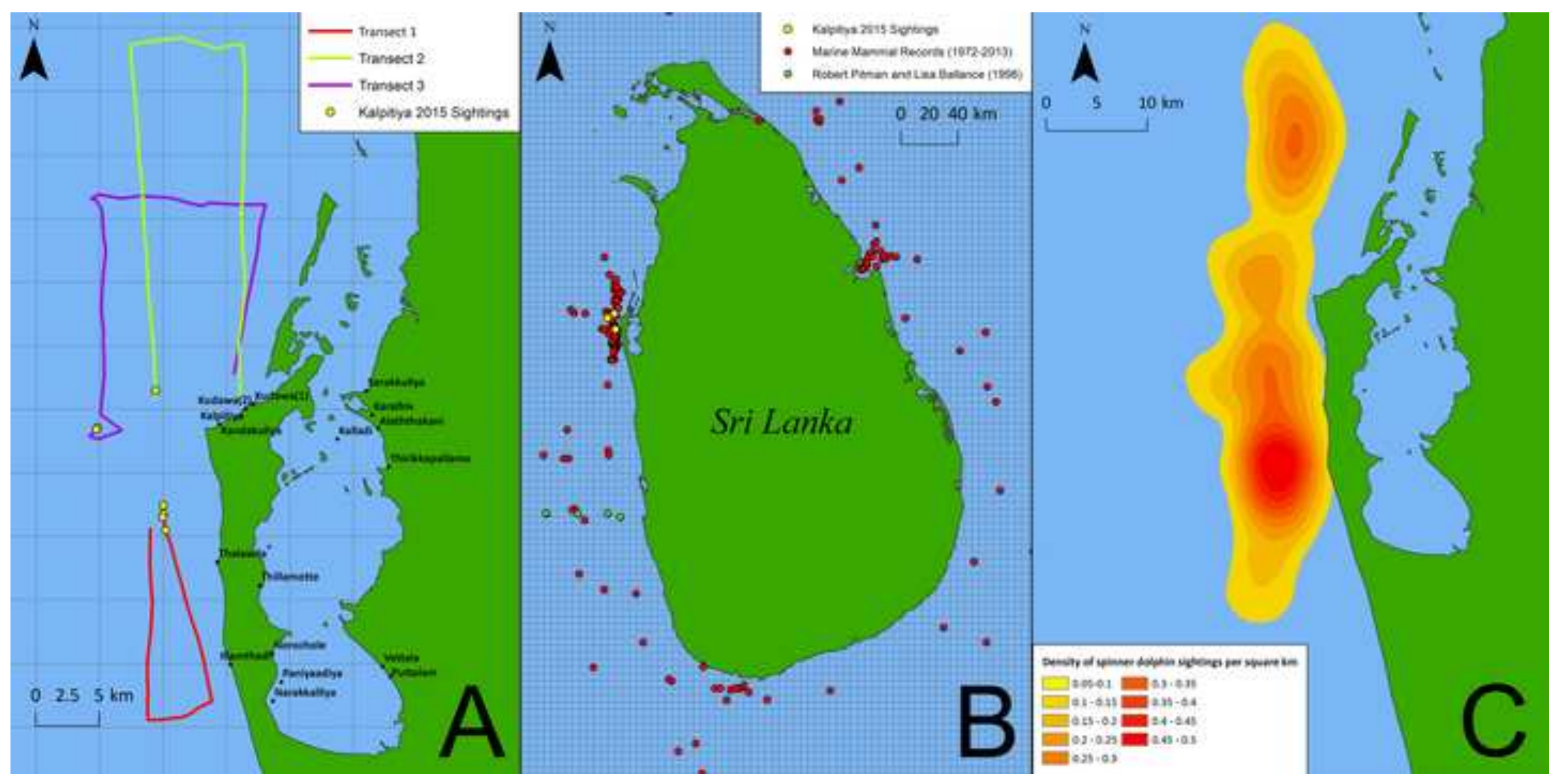


Click here to download high resolution image

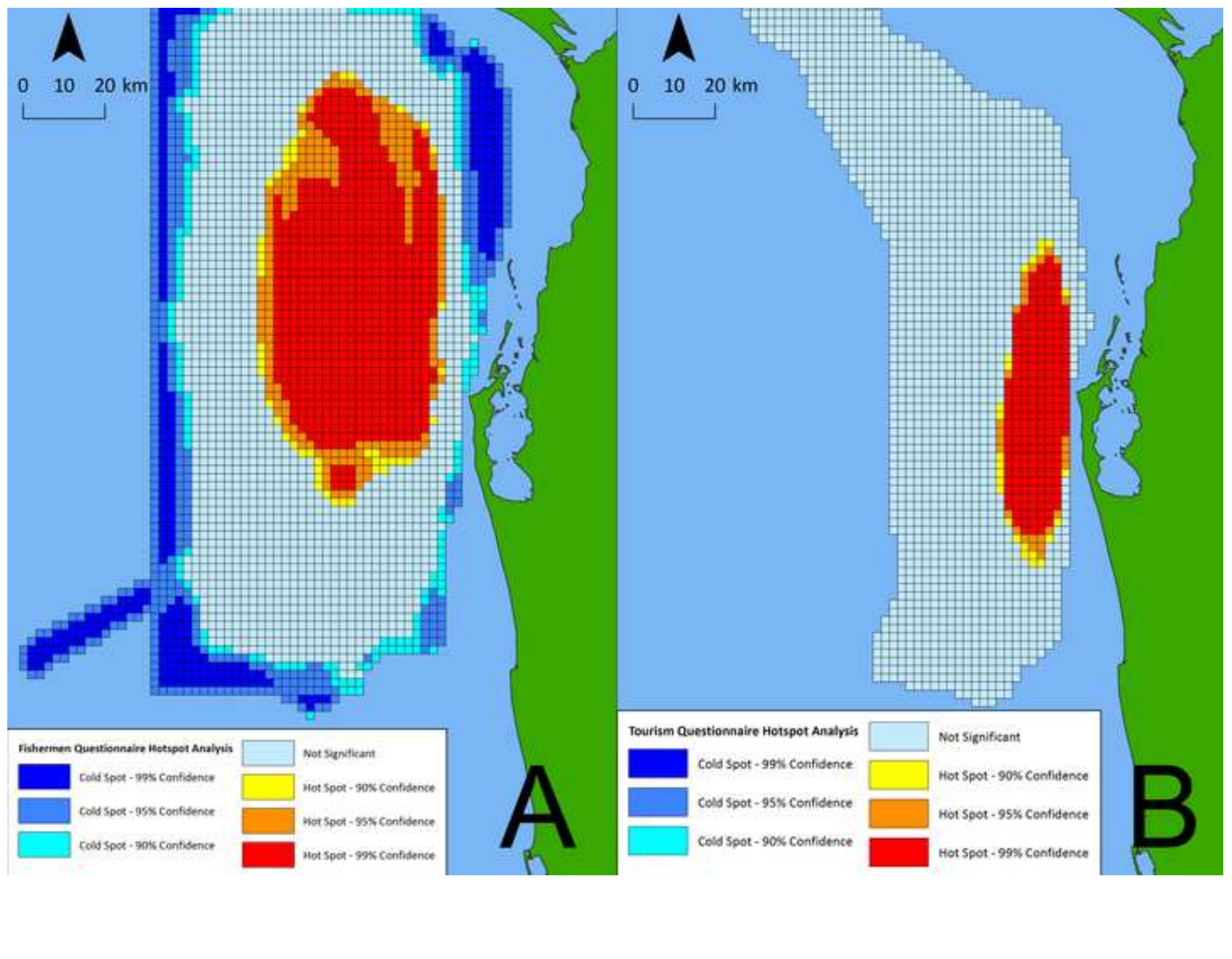

Motspot-gavemisente
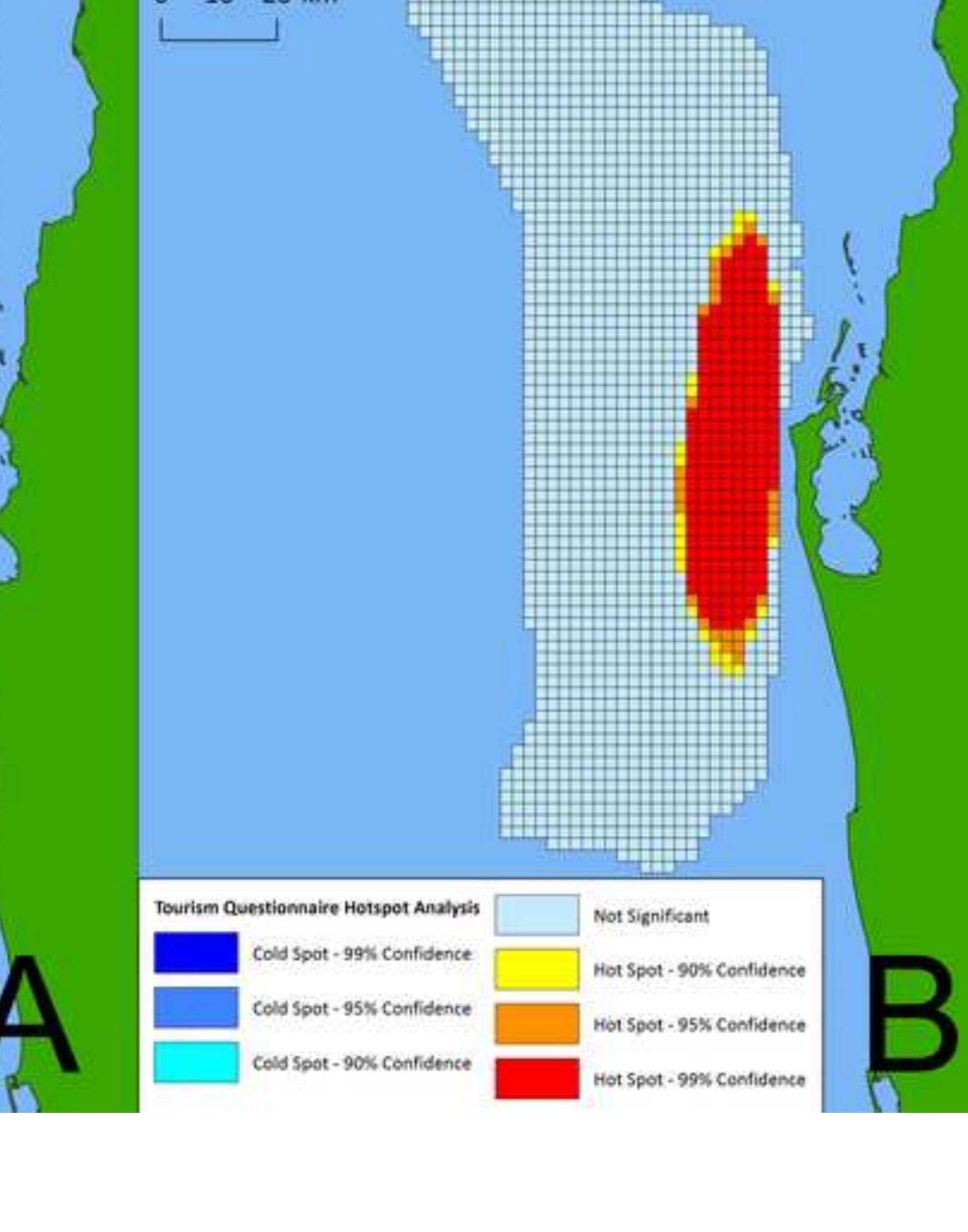
Click here to download high resolution image

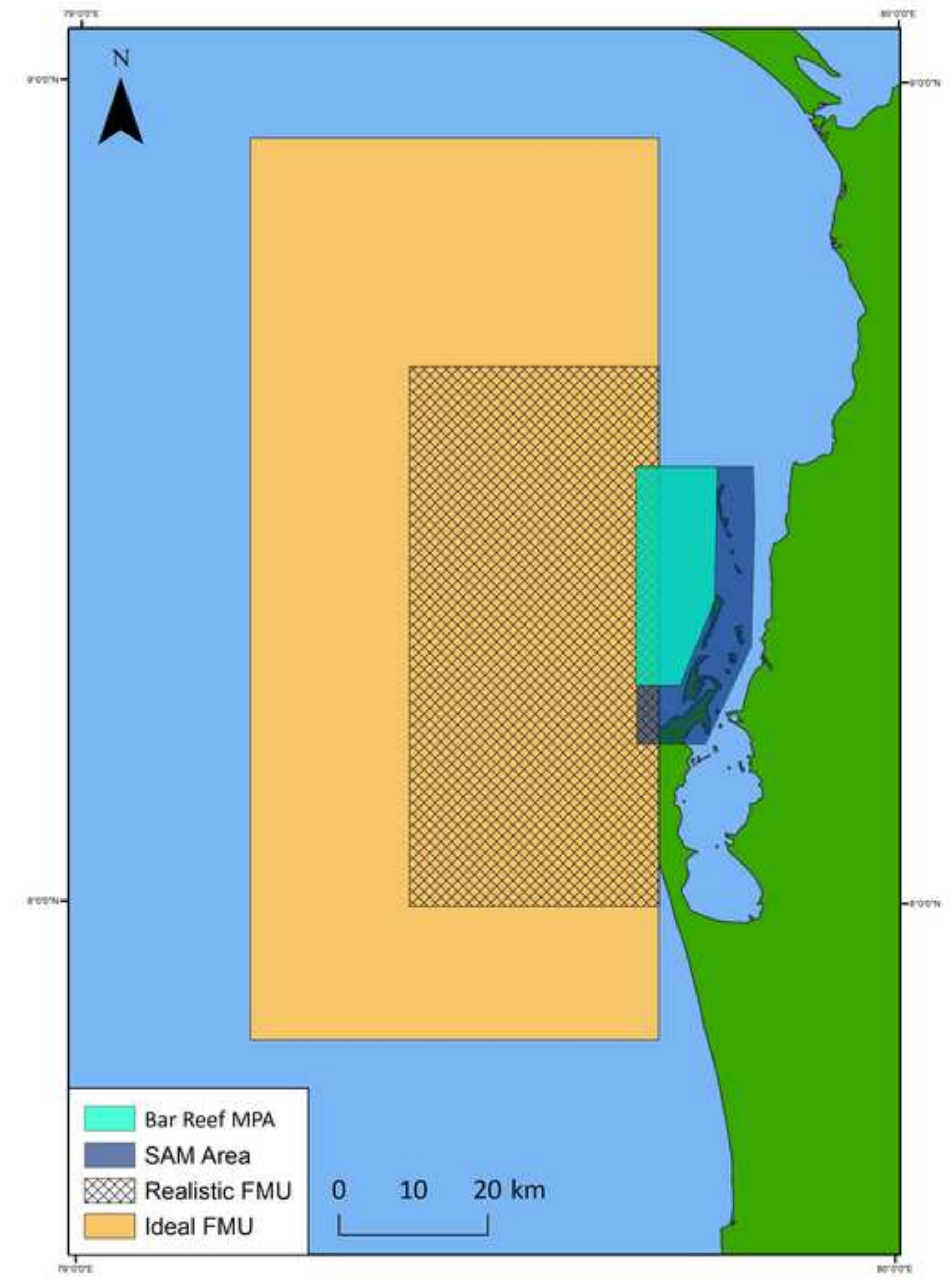

Figure 3
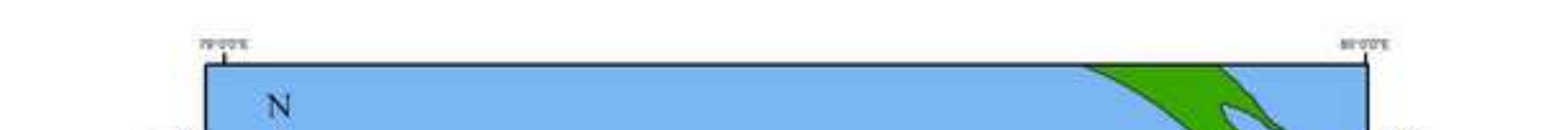


\section{Click here to download high resolution image}

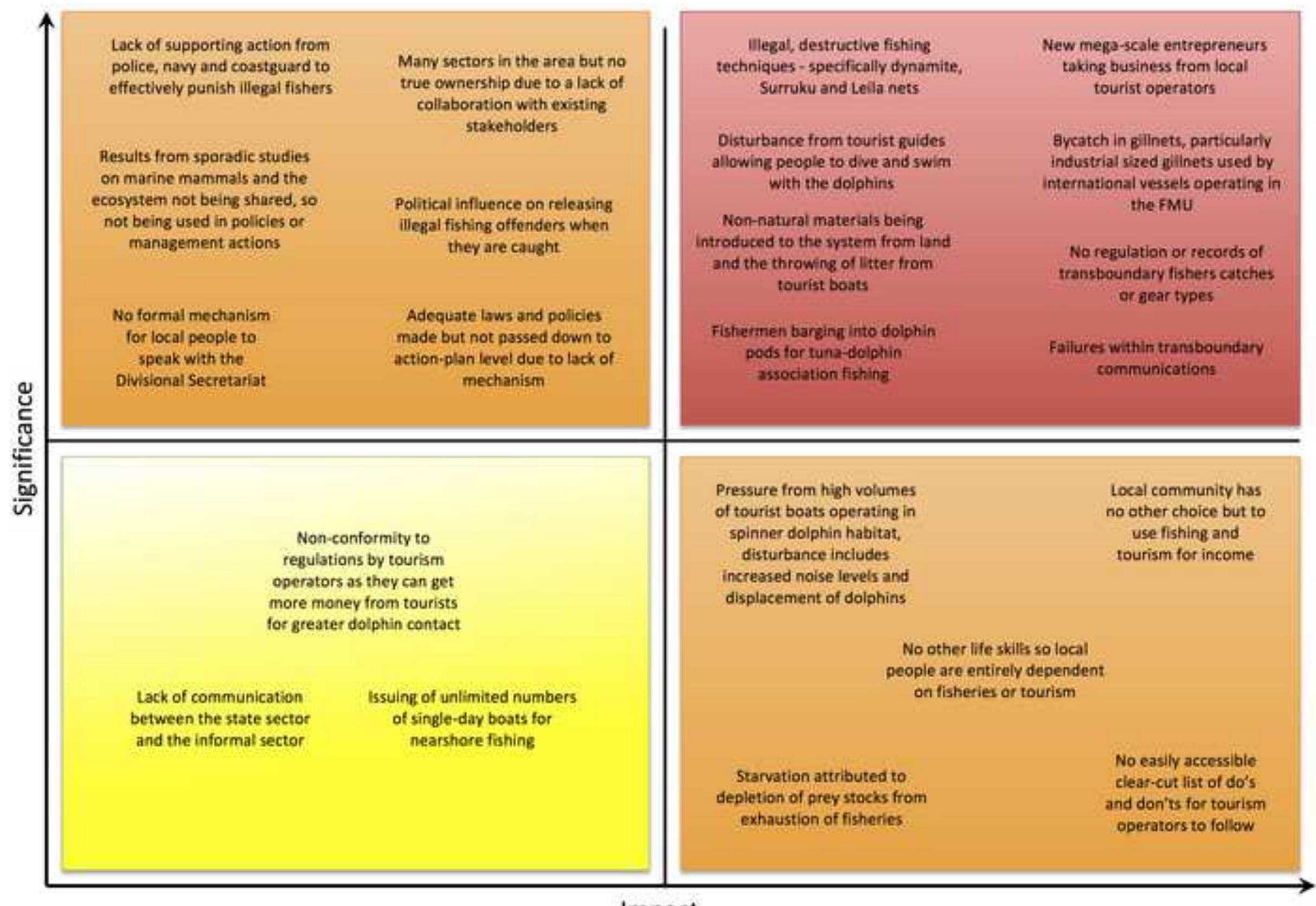

Impact 
Click here to download high resolution image

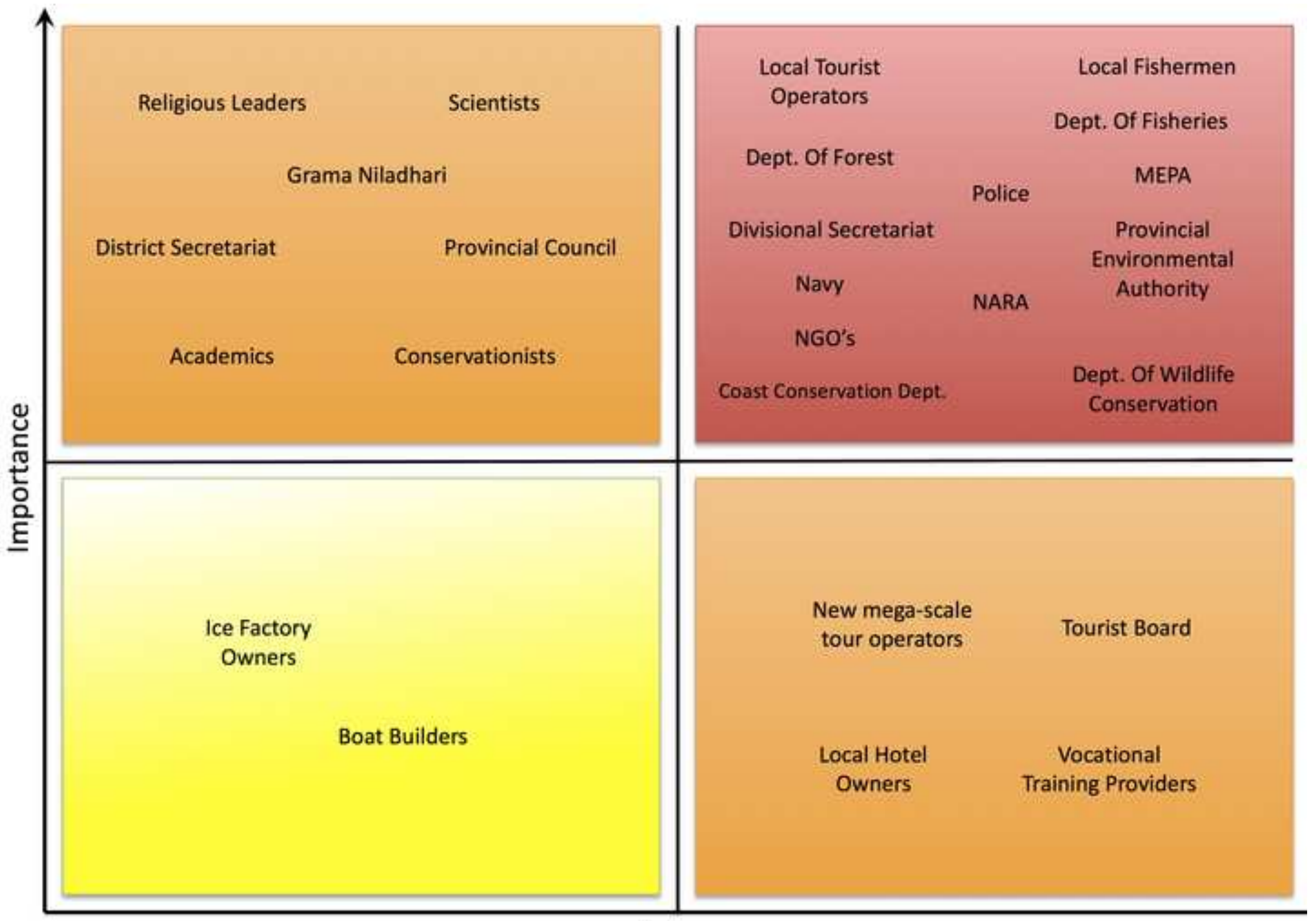




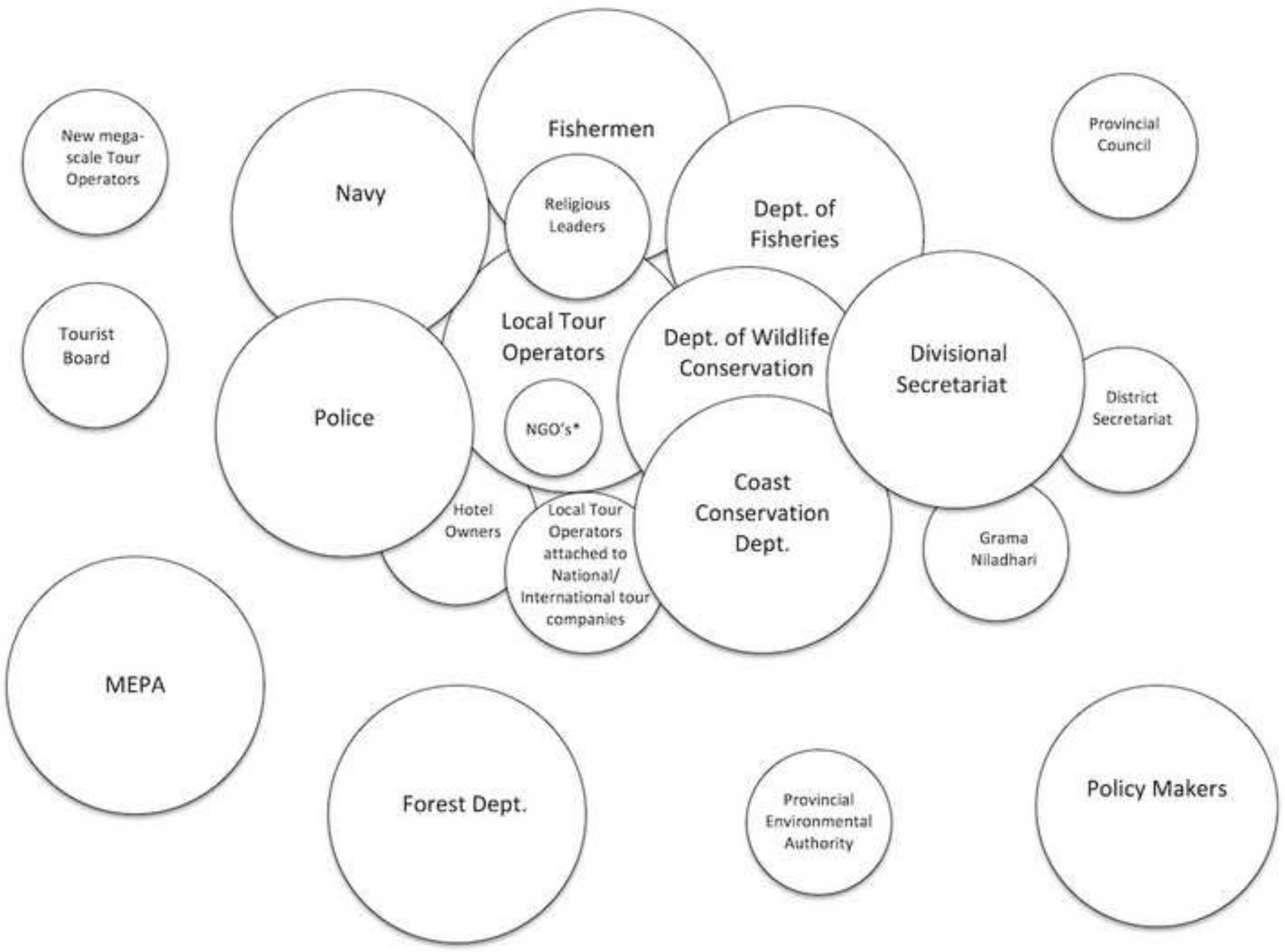


Figure captions:

Figure 1: (A) Spinner dolphin sightings from transect surveys around the Kalpitiya coast between April and May 2015. (B) Compiled GPS sightings of spinner dolphins around Sri Lanka from 1972-2015. (C) Kernel smoothing interpolation of spinner dolphin sightings density in northwest Sri Lanka using GPS data from 1972-2015.

Figure 2: Maps showing results of Getis-Ord Gi* hotspot analysis on the fishermen perceptions of spinner dolphin core area (A) Fishermen (B) Tourism Operators.

Figure 3: Current institutional management boundaries and the ideal and realistic fisheries management units proposed for the EAFM plan.

Figure 4: Threats matrix. Upper right: The most significant, high impact threats to the spinner dolphin population and the Kalpitiya marine ecosystem. Upper left and lower right: The slightly less serious but still important threats. Bottom left: The lowest impact and least significant threats.

Figure 5: Stakeholder matrix. Upper right: The most important and influential stakeholders of the Kalpitiya marine system. Upper left and lower right: The stakeholders who are slightly less integral to the system. Bottom left: The stakeholders of least importance and influence to the system.

Figure 6: Venn diagram representing relationships between stakeholders of the Kalpitiya marine system, with the larger diameter circles representing the most influential stakeholders and distance between circles indicating communication gaps that require addressing ( ${ }^{*} \mathrm{NGO}$ 's include the Turtle Conservation Project, World Vision, ORCA and IUCN). 
Table 1: Explanatory variables used to test if there are influences on the perceptions of spinner dolphin core area and the descriptions of the impacts these variables may have on the area impressions

\begin{tabular}{|c|c|l|}
\hline $\begin{array}{c}\text { Explanatory } \\
\text { Variable }\end{array}$ & $\begin{array}{c}\text { Fisherman or } \\
\text { Tourist Operator } \\
\text { Variable }\end{array}$ & $\begin{array}{l}\text { Impact this may have on the impression of spinner dolphin } \\
\text { core area }\end{array}$ \\
\hline $\begin{array}{c}\text { Tuna Target } \\
\text { Species }\end{array}$ & $\mathrm{F}$ & $\begin{array}{l}\text { Tuna fishermen may have a more specific idea of the size of the spinner } \\
\text { dolphins' core area compared to non-target fishermen due to fishing } \\
\text { using tuna-dolphin associations. }\end{array}$ \\
\hline Gear Type & $\mathrm{F}$ & $\begin{array}{l}\text { Fishers using mobile gear types may have greater experience in larger } \\
\text { areas of the sea than those using mobile types, so may have had greater } \\
\text { numbers of spinner dolphin encounters and define a larger core area. }\end{array}$ \\
\hline Experience & $\mathrm{F}$ and T & $\begin{array}{l}\text { Fishermen and tourism operators with more years experience fishing may } \\
\text { have a more widespread impression of the true spinner dolphin core } \\
\text { area. }\end{array}$ \\
\hline $\begin{array}{c}\text { Maximum } \\
\text { Distance } \\
\text { From Coast }\end{array}$ & $\mathrm{F}$ & $\begin{array}{l}\text { The fishermen that travel further away from the coast may suggest a } \\
\text { larger core area, as they spend more time out at sea compared to those } \\
\text { who only stay nearshore. }\end{array}$ \\
\hline Migration & $\mathrm{F}$ & $\begin{array}{l}\text { The non-migratory fishermen who remain in the area longer may perceive } \\
\text { larger areas of spinner dolphin core habitat. }\end{array}$ \\
\hline Vessel Size & $\mathrm{F}$ and T & $\begin{array}{l}\text { Fishermen and tourist operators that have larger vessels may cover wider } \\
\text { areas and may be able to spend more time at sea, therefore perceiving } \\
\text { larger spinner dolphin core area. }\end{array}$ \\
\hline $\begin{array}{c}\text { Service } \\
\text { Provided }\end{array}$ & $\mathrm{T}$ & $\begin{array}{l}\text { The tourist operators that provide the most services may cover a more } \\
\text { widespread area in the region so perceive larger areas of spinner dolphin } \\
\text { core habitat. }\end{array}$ \\
\hline
\end{tabular}


Table 2: Schedule containing topics discussed and exercises completed in the stakeholder workshop

\begin{tabular}{|l|l|}
\hline $\begin{array}{l}\text { Workshop } \\
\text { Section }\end{array}$ & Discussion topics and activities \\
\hline $\mathbf{1}$ & $\begin{array}{l}\text { Presentation of decided FMU and explanation of how questionnaire/sightings data were used to } \\
\text { determine it }\end{array}$ \\
\hline $\mathbf{2}$ & $\begin{array}{l}\text { Presentation and discussion of predetermined threats extracted from interviews } \\
\text { Addition of missing threats and ranking of all threats in a matrix of impact and significance }\end{array}$ \\
\hline $\mathbf{3}$ & $\begin{array}{l}\text { Presentation of suggested goals for the EAFM plan } \\
\text { Discussion of actions to be taken to achieve the goals and address all previously determined } \\
\text { threats }\end{array}$ \\
\hline & $\begin{array}{l}\text { Completion of stakeholder exercises: Stakeholder relationships indicated in the form of a Venn } \\
\text { diagram to show communication gaps and in a matrix to rank stakeholders on influence and } \\
\text { importance } \\
\text { Decision on members to be part of the EAFM implementing committee }\end{array}$ \\
\hline
\end{tabular}


Table 3: Results from fishermen questionnaires describing their demographic and business traits and their estimations regarding characteristics of the Kalpitiyan spinner dolphin population

\begin{tabular}{|c|c|c|c|}
\hline \multicolumn{2}{|c|}{ Demographic/business characteristics } & \multicolumn{2}{|c|}{ Spinner dolphin population characteristics } \\
\hline Mean age (years) & $36.32( \pm 10.99)$ & Mean pod size & $\begin{array}{c}3627.52 \\
( \pm 5275.38)\end{array}$ \\
\hline $\begin{array}{c}\text { Village of residence (\%) } \\
\text { Kandakuliya } \\
\text { Baththalangunduwa } \\
\text { Sinhapura } \\
\text { Anawasala } \\
\text { Janasauipuru } \\
\text { Kurakkanhena }\end{array}$ & $\begin{array}{c}44 \\
24 \\
20 \\
4 \\
4 \\
4\end{array}$ & $\begin{array}{c}\text { Spinner dolphin sighting } \\
\text { frequency (\%) } \\
\text { Never } \\
\text { Rarely } \\
\text { Often } \\
\text { Regularly }\end{array}$ & $\begin{array}{c}4 \\
8 \\
16 \\
72\end{array}$ \\
\hline Mean experience (years) & $20.76( \pm 9.90)$ & $\begin{array}{c}\text { Spinner dolphin migration (\%) } \\
\text { Yes } \\
\text { No }\end{array}$ & $\begin{array}{l}21 \\
79\end{array}$ \\
\hline $\begin{array}{c}\text { Vessel Size (\%) } \\
0-10 \text { metres } \\
11-15 \text { metres }\end{array}$ & $\begin{array}{l}80 \\
20\end{array}$ & $\begin{array}{c}\text { Dolphin population constant? (\%) } \\
\text { Yes } \\
\text { No }\end{array}$ & $\begin{array}{l}30 \\
70\end{array}$ \\
\hline $\begin{array}{l}\text { Maximum distance fished } \\
\text { from coast (\%) } \\
0-19 \text { kilometres } \\
20-39 \text { kilometres } \\
40-59 \text { kilometres } \\
60-79 \text { kilometres } \\
80+\text { kilometres }\end{array}$ & $\begin{array}{l}20 \\
16 \\
40 \\
12 \\
12\end{array}$ & $\begin{array}{c}\text { Gear types dolphins get entangled } \\
\text { in (\%) } \\
\text { Seine nets } \\
\text { Gill/drift nets } \\
\text { Longlines } \\
\text { Trawls } \\
\text { Other }\end{array}$ & $\begin{array}{c}0 \\
68 \\
0 \\
0 \\
32\end{array}$ \\
\hline $\begin{array}{c}\text { Gear type used (\%) } \\
\text { Lines } \\
\text { Nets } \\
\text { Both }\end{array}$ & $\begin{array}{l}36 \\
24 \\
40\end{array}$ & $\begin{array}{c}\text { Lagoon presence (\%) } \\
\text { Yes } \\
\text { No }\end{array}$ & $\begin{array}{c}0 \\
100\end{array}$ \\
\hline $\begin{array}{c}\text { Fisherman migration (\%) } \\
\text { Yes } \\
\text { No }\end{array}$ & $\begin{array}{l}48 \\
52\end{array}$ & $\begin{array}{c}\text { Dolphins caught by accident or on } \\
\text { purpose? }(\%) \\
\text { Accident } \\
\text { Purpose }\end{array}$ & $\begin{array}{c}96 \\
4\end{array}$ \\
\hline $\begin{array}{c}\text { Target species fished (\%) } \\
\text { Tuna } \\
\text { Non-specialist }\end{array}$ & $\begin{array}{l}48 \\
52\end{array}$ & $\begin{array}{c}\text { Dolphins entangled in own gear? } \\
(\%) \\
\text { Yes } \\
\text { No }\end{array}$ & $\begin{array}{l}24 \\
76\end{array}$ \\
\hline
\end{tabular}


Table 4: Results from tourism operator questionnaires describing their demographic and business traits and their estimations regarding characteristics of the Kalpitiyan spinner dolphin population

\begin{tabular}{|c|c|c|c|}
\hline \multicolumn{2}{|c|}{ Demographic/business characteristics } & \multicolumn{2}{|c|}{ Spinner dolphin population characteristics } \\
\hline Mean age (years) & $35.1( \pm 9.9)$ & Mean pod size & $8397.4( \pm 12853.9)$ \\
\hline $\begin{array}{c}\text { Village of residence (\%) } \\
\text { Kandakuliya } \\
\text { Kudawa } \\
\text { Chilaw } \\
\text { Negombo } \\
\text { Ilanthiadiya }\end{array}$ & $\begin{array}{l}36 \\
36 \\
14 \\
7 \\
7\end{array}$ & $\begin{array}{c}\text { Spinner dolphin sighting } \\
\text { frequency (\%) } \\
\text { Never } \\
\text { Rarely } \\
\text { Often } \\
\text { Reqularly }\end{array}$ & $\begin{array}{c}0 \\
7 \\
0 \\
93\end{array}$ \\
\hline Mean experience (years) & $6.9( \pm 5.2)$ & $\begin{array}{c}\text { Spinner dolphin migration } \\
(\%) \\
\text { Yes } \\
\text { No }\end{array}$ & $\begin{array}{c}7 \\
93\end{array}$ \\
\hline $\begin{array}{c}\text { Vessel Size (\%) } \\
0-5 \text { metres } \\
5-10 \text { metres }\end{array}$ & $\begin{array}{c}92 \\
8\end{array}$ & $\begin{array}{c}\text { Lagoon presence } \\
\text { Yes } \\
\text { No }\end{array}$ & $\begin{array}{c}0 \\
100\end{array}$ \\
\hline $\begin{array}{l}\text { Service provided (\%) } \\
\text { Dolphin watching/Scuba } \\
\text { Dolphin watching/Scuba/Other } \\
\text { Dolphin watching/Other }\end{array}$ & $\begin{array}{l}21 \\
57 \\
22\end{array}$ & $\begin{array}{c}\text { Spinner dolphin population } \\
\text { constant? (\%) } \\
\text { Yes } \\
\text { No }\end{array}$ & $\begin{array}{l}36 \\
64\end{array}$ \\
\hline
\end{tabular}


Table 5: Percentages of willingness and unwillingness of fishermen (response variables 1 and 2) and tour operators (response variables 3 and 4) to change for the four binomial response variables

\begin{tabular}{|l|l|l|l|l|}
\hline Response variables & $\begin{array}{l}\text { 1. Willingness to } \\
\text { modify fishing gear } \\
\text { to improve spinner } \\
\text { dolphin } \\
\text { conservation }\end{array}$ & $\begin{array}{l}\text { 2. Willingness to } \\
\text { fish in different } \\
\text { areas to improve } \\
\text { spinner dolphin } \\
\text { conservation }\end{array}$ & $\begin{array}{l}\text { 3. Willingness to } \\
\text { conform to vessel } \\
\text { speed limits and } \\
\text { distance buffers for } \\
\text { spinner dolphin } \\
\text { conservation }\end{array}$ & $\begin{array}{l}\text { 4. Willingness to } \\
\text { avoid operating in } \\
\text { specific areas to } \\
\text { provide rest refuges } \\
\text { in dolphin core } \\
\text { habitat }\end{array}$ \\
\hline Willing (\%) & 52 & 24 & 100 & 71 \\
\hline Not Willing (\%) & 48 & 76 & 0 & 29 \\
\hline
\end{tabular}


Table 6: Table showing threats to human, ecological and governance wellbeing agreed by stakeholders

\begin{tabular}{|c|c|c|}
\hline Governance Threats & Socio-economic Threats & Ecological Threats \\
\hline $\begin{array}{l}\text { Failures within transboundary } \\
\text { communications }\end{array}$ & $\begin{array}{l}\text { Local community has no other choice } \\
\text { but to use fishing and tourism for } \\
\text { income }\end{array}$ & $\begin{array}{l}\text { Illegal, destructive fishing } \\
\text { techniques. Specifically dynamite, } \\
\text { surruku and Leila nets }\end{array}$ \\
\hline $\begin{array}{l}\text { No regulation or records of } \\
\text { transboundary fishers catches or gear } \\
\text { types }\end{array}$ & $\begin{array}{l}\text { Non-conformity to regulations by } \\
\text { tourism operators as they can get } \\
\text { more money from tourists for greater } \\
\text { dolphin contact }\end{array}$ & $\begin{array}{l}\text { Disturbance from tourist guides } \\
\text { allowing people to dive and swim } \\
\text { with the dolphins }\end{array}$ \\
\hline $\begin{array}{l}\text { Lack of supporting action from police, } \\
\text { navy and coastguard to effectively } \\
\text { punish illegal fishers }\end{array}$ & $\begin{array}{l}\text { Lack of communication between the } \\
\text { state sector and the informal sector }\end{array}$ & $\begin{array}{l}\text { Flotsam disturbance, plastics and } \\
\text { other non-natural materials are being } \\
\text { introduced to the system from land } \\
\text { and the throwing of litter from tourist } \\
\text { boats }\end{array}$ \\
\hline $\begin{array}{l}\text { Many sectors in the area but no true } \\
\text { ownership due to a lack of } \\
\text { collaboration with existing } \\
\text { stakeholders }\end{array}$ & $\begin{array}{l}\text { Local people have no other life skills } \\
\text { that would relieve some of the } \\
\text { pressure from fishing and tourism }\end{array}$ & $\begin{array}{l}\text { Fishermen barging into dolphin pods } \\
\text { for tuna-dolphin association fishing }\end{array}$ \\
\hline $\begin{array}{l}\text { Adequate laws and policies made but } \\
\text { not passed down to action-plan level }\end{array}$ & $\begin{array}{l}\text { New mega-scale entrepreneurs taking } \\
\text { business from local tour operators }\end{array}$ & $\begin{array}{l}\text { Pressure from high volumes of } \\
\text { tourist boats operating in spinner } \\
\text { dolphin habitat, disturbance includes } \\
\text { increased noise levels and } \\
\text { displacement of dolphins }\end{array}$ \\
\hline $\begin{array}{l}\text { No easily accessible clear-cut list of } \\
\text { do's and don'ts for tourism operators } \\
\text { to follow }\end{array}$ & $\begin{array}{l}\text { No formal mechanism for local people } \\
\text { to speak with the Divisional Secretariat }\end{array}$ & $\begin{array}{l}\text { Bycatch in gillnets, particularly } \\
\text { industrial sized gillnets used by } \\
\text { international vessels operating in the } \\
\text { FMU }\end{array}$ \\
\hline $\begin{array}{l}\text { Results from sporadic studies on } \\
\text { marine mammals and the ecosystem } \\
\text { not being shared so not being used in } \\
\text { policies or management actions }\end{array}$ & & $\begin{array}{l}\text { Starvation attributed to depletion of } \\
\text { prey stocks from exhaustion of } \\
\text { fisheries }\end{array}$ \\
\hline $\begin{array}{l}\text { Issuing of unlimited numbers of single- } \\
\text { day boats for nearshore fishing }\end{array}$ & & $\begin{array}{l}\text { Political influence on releasing illegal } \\
\text { fishing offenders when they are } \\
\text { caught }\end{array}$ \\
\hline
\end{tabular}




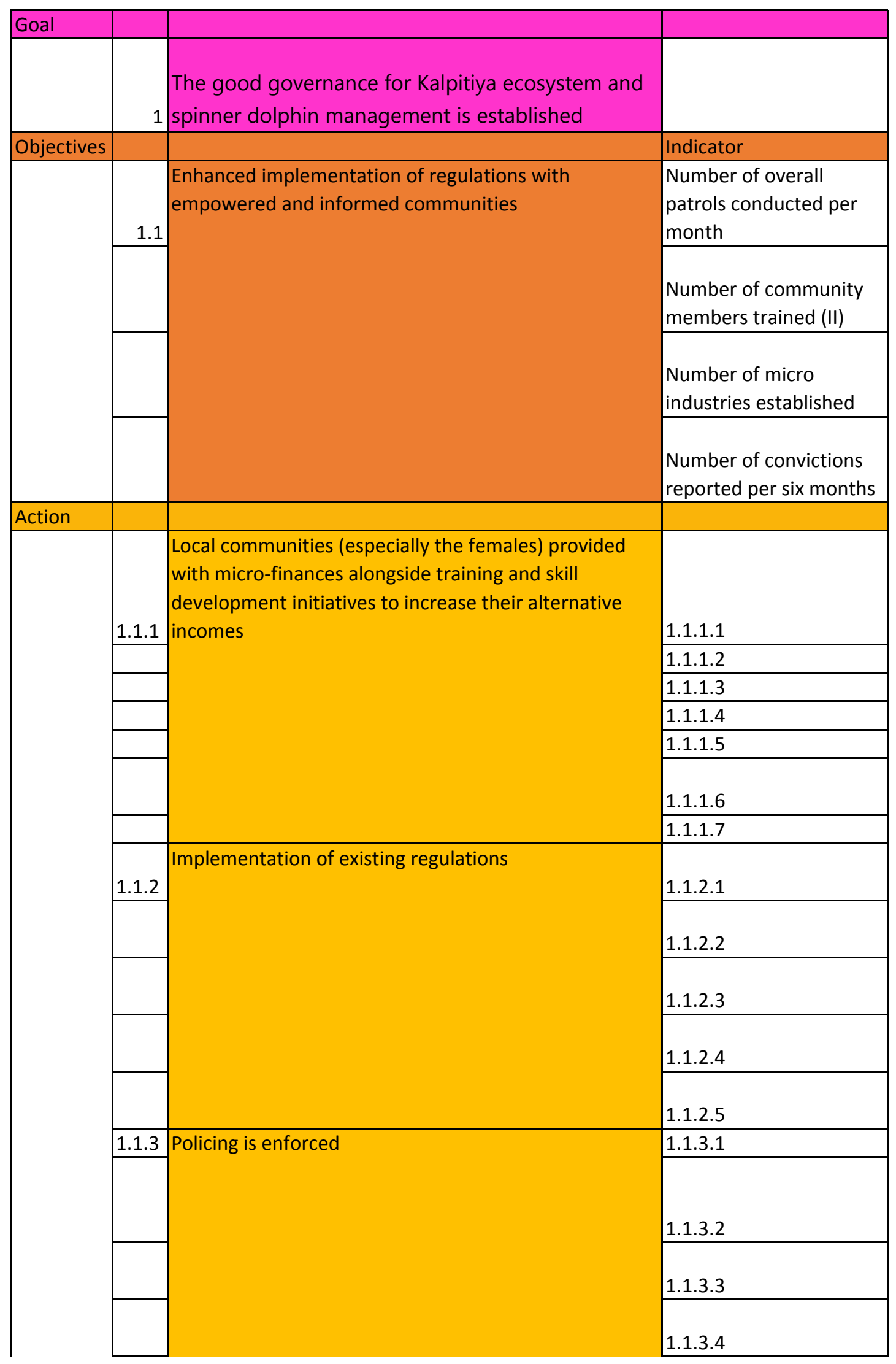

